\title{
Investors' Reaction to the Implementation of Corporate Governance Mechanisms
}

\author{
Nousheen Tariq Bhutta*, Syed Zulfiqar Ali Shah \\ Faculty of Management Sciences, International Islamic University, Islamabad, Pakistan \\ Email: imaantariq@gmail.com, zulfiqar.shah@gmail.com
}

Received May 16, 2013; revised June 28, 2013; accepted July 9, 2013

Copyright (C) 2014 Nousheen Tariq Bhutta, Syed Zulfiqar Ali Shah. This is an open access article distributed under the Creative Commons Attribution License, which permits unrestricted use, distribution, and reproduction in any medium, provided the original work is properly cited. In accordance of the Creative Commons Attribution License all Copyrights (C) 2014 are reserved for SCIRP and the owner of the intellectual property Nousheen Tariq Bhutta, Syed Zulfiqar Ali Shah. All Copyright (C) 2014 are guarded by law and by SCIRP as a guardian.

\begin{abstract}
The study investigates the impact of corporate governance on investor reaction. This is the first study till date that addresses this gap in literature. The design of the study comprises of corporate governance, investor reaction. Data was taken from 125 non-financial sector of Pakistani companies listed at KSE for the period of 2005-2010. Data was extracted from balance sheet analysis (SBP report), KSE website and annual reports of companies. Correlation (individual and composite) and linear regression tests were applied to validate the outcomes. The results confirm that there is no impact of corporate governance on investor reaction and relationship between them is negative. This implies the inefficiency of financial market where noise trades create sentiment.
\end{abstract}

\section{KEYWORDS}

\section{Corporate Governance; Investor Reaction; Emerging Market}

\section{Introduction}

Corporate governance is an important component for profitability and growth of firms through achieving the allocative efficiency, so that scarce funds were transferred to investment projects with higher returns. Generally, efficiency can be achieved if the investment projects offer higher returns as compared to cost of capital [1]. Corporate governance mechanism provides protection to shareholders and other stakeholder particularly investors. Good governance practices help to increase the share prices that could get higher capital. It also facilitates the international investor to lend money and purchase shares in domestic companies [2].

$[3,4]$ investigated the market reaction to corporate governance mechanism. They argued that those firms which were greatly affected from such governance practices reacted more profoundly as compared to firms exhibiting good governance practices. Furthermore, [5] investigated the market reaction to corporate governance practices. They criticized the governance practices are value de-

*Corresponding author. stroying as they found abnormal return, reducing in CEO pay, number of large block holders, easiness of institutional investors and presence of a staggered board.

Although, researchers scrutinized the market reaction to corporate governance mechanism, but there is no study till date that investigates impact of corporate governance mechanism on investor reaction. So the specialty of this study is to gain the attention of academicians and practitioners by bridging this gap in literature.

Two research questions has been addressed which are:

- Does corporate governance impact the investor behavior?

- Is this relationship significant across different economies?

This study confirms that the corporate governance mechanism impacts insignificantly on investor reaction.

This paper is organized in a way that the first section describes the introduction of the study followed by literature review to build theoretical framework. The next one discusses the methodology, followed by discussion of the results and conclusion; the last section explains the managerial implications and future research direction. 


\section{Literature Review}

Corporate governance is a "process whereby suppliers of capital (shareholders) attempt to ensure that managers of the firms in which they invest provide a sufficient return. It addresses the agency problem whereby the shareholders (principals) are the ultimate owners of the firm and want to ensure that managers (agents), who are separate from the shareholders, act in the shareholders' best interests rather than the interests of managers" [6].

[6] scrutinized the link between measures of corporate governance and stock returns. They highlighted that high governance ranking firms outperform than other portfolios. Moreover, market reacts significantly to governance related information which reflects that good governance does matters to Canadian investors. Similarly, [7] investigated the price reaction to corporate governance announcements. They confirmed that investors react to these governance practices but the sign of their reaction depend upon the extension and nature of these types of announcements. Moreover, [8] studied the corporate governance mechanisms and market reaction and liquidity impact. They depicted that market price reaction is significant positive when firm committed for higher transparency and minority shareholder protection in its announcement. Furthermore, shares having voting rights experience stronger price reaction and liquidity enhancement rather than non-voting shares. They suggested that corporate governance mechanism can be effective strategy for countries having weak investor protection provisions.

Corporate Governance announcements are important ways for interacting with the investors. [9] demonstrated the link between corporate governance rating announcements and stock returns of companies. By using event study, they analyzed the 11 top listed corporate governance companies for the period of 2004-2005 and found no relationship between corporate governance and share performance of firms, might be attributable to perception of Thai investors. [5] scrutinized the link between market reaction to corporate governance regarding to regulatory and legislative actions. They proved that abnormal returns relating to corporate governance mechanism are reduction in number of large bondholders, CEO pay, ease of institutional investors to access the proxy method and presence of stagnant board. [10] studied that how corporate governance would impact the market reaction to earning surprise regarding to post earnings announcements drift. They confirmed the investor 'reactions both, over-reaction and under-reaction to earnings surprises can create post earnings announcement drift. They investigated for bad governance firms, that investor would under-react to earnings surprises as they believed that earnings surprises might be attributable to firm's luck rather than its ability. On the other scenario i.e. for good governance firms, they scrutinized that investor would over-react to earnings surprises as they believed that earnings surprises are attributable to firm's ability rather than its luck. [11] studied the role of corporate governance in abnormal returns regarding to seasonal equity offerings. They confirmed that investors react positively for companies in which people hold the CEO and chairman positions. Moreover, investor reacts positively for companies having high outsider members, low CEO ownership and small board size. They highlighted that investors also react positively to seasonal equity offerings by companies having stronger corporate governance mechanism that ultimately reduces the agency problems.

[12] demonstrated the relationship between governance and asymmetric information and other imperfections that usually firm faces. They found that corporate governance is highly related to high market valuation and operating performance. They highlighted that countries having weak legal system are more probable to firm level corporate governance mechanism. [13] examined the firm announcement that is negatively valued by investor might be attributable to information asymmetry and its adverse features. They also depicted that stronger corporate governance mechanisms experience low price decline from the information symmetry, transpiring that strong corporate governance mechanism might mitigate the agency problems.

[14] explored the impact of corporate governance on investment decisions. They proved that strong corporate governance structure can ease the investment decisions. Owner-owned firms get less financial distress and more positive stock evaluation than management controlled firms, reflecting that firms with better corporate governance practices can get positive investor evaluation from investors. [15] depicted the effectiveness of corporate governance mechanism for increasing capital and Research and development investment decisions. They found that higher ownership governance yields greater abnormal returns to capital investment decisions however; higher board governance mechanism yields abnormal returns to research and development investment decisions.

Institutional investors play a vital role in corporate governance activities like [16] examined the institutional investors would impact the corporate governance through analyzing the portfolio holdings of institutions in companies over the period of 2003-2008. They proved that change in institutional investment would bring positive change in firm level governance; however, they did not find any impact of governance on institutional investments. Furthermore, they highlighted that firms having higher institutional ownership could easily terminate poorly performing chief executives and made further improvements. [17] investigated the corporate gover- 
nance mechanism and investor protection. They found that investor's evaluation of investor protection regimes are related to firm-level corporate governance mechanism along with characteristics of their portfolio holdings. They also depicted that firm level corporate governance are attributable to mitigation of agency problems between large and small shareholders, irrespective of weaker investor protection. Furthermore, countries having weak legal structure might be attributable to attract investors through having strong corporate governance regime. The investor preferences for country level investor protection and good corporate governance mechanism are highly related to investment decisions.

[18] investigated that governance-sensitive institutions is related to improvement in shareholder rights. They also confirmed that low turnover institutions with preference for small cap and growth companies are attributable to be more governance sensitive. Furthermore, they suggested that common proxies for governance sensitivity do not measure governance preference clearly.

[19] scrutinized the relationship between governance mechanisms and firm investment choices by using Real Estate Investment Trusts (REITs) as a sample. They highlighted that responsiveness of REITs' investment opportunities depend upon their corporate governance structures. Moreover, REITs have higher institutional ownership, then their investment opportunities are closely related to Tobin's q. However, Real Estate Investment Trusts (REITs) may vitiate the effectiveness of internal governance mechanism. They found that information asymmetry diminished by REIT governance. Furthermore, they confirmed that high financial incentives for board members along with experienced board members and independent audit committee having financial expertise reduces asymmetric information [20].

From above discussion it can be inferred that corporate governance mechanism impacts the investor reaction positively. Therefore, a proposed hypothesis is.

H1: Corporate governance mechanism has a significant impact on investor reaction.

\section{Methodology}

Methodology portion comprises of two sections. One describes the variables, proxies and data collection and other highlights the statistical tests applied on the data. The aim of current study is to investigate impact of corporate governance mechanism on investor reaction. Therefore, data has been collected for the 125 non-financial sector of Pakistani companies listed at Karachi Stock Exchange, for the period of 2005-2010 on yearly basis. Data was extracted from Balance sheet analysis (SBP report), KSE website and annual reports of companies.

\subsection{Variables}

Corporate governance mechanism has been taken as independent variable and investor reaction has been taken as dependent variable.

\subsection{Equation}

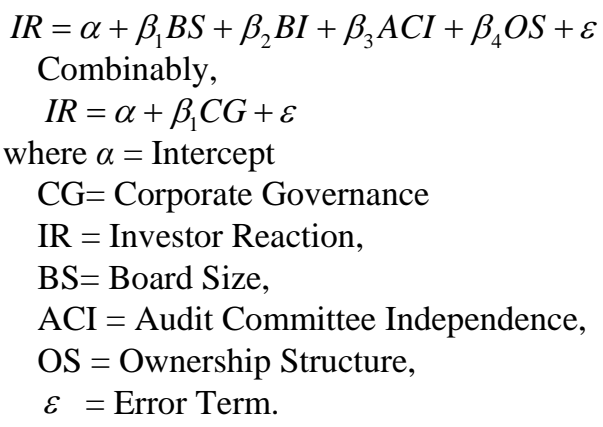

\subsection{Proxies}

\section{1) Corporate Governance}

Corporate Governance can be measured through four proxies:

- Board size $=$ Natural log of Number of Total Directors

- Board independence $=$ Number of Non Executive Directors divided by Total Number of Directors

- Audit Committee independence $=$ Number of Non Executive Directors divided by Total Number of Audit Committee Members

- Ownership Structure $=$ Shares held by Directors divided by Total Shares

\section{2) Investor reaction}

Investor reaction can be measured through stock returns.

Stock Returns $=$ Natural $\log$ of $\mathrm{Pn} / \mathrm{Po}$

\section{3) Methodological Tests}

- Correlation test has applied to find out the interrelationship between variables.

- Linear regressions have applied to check the hypothesis.

\section{Result and Discussion}

\section{1) Correlation}

Correlation tests were used to find out inter-relationship among Corporate Governance and Investor Reaction. The findings highlight that Investor Reaction (IS). Tables 1 and 2 depict the correlation analysis.

Table 1 shows the correlation between variables of corporate governance and investor reaction. It depicts that board size is negatively related to director independence, ownership structure and investor reaction while it is positively related to audit committee independence. Director Independence is positively related to audit 
committee independence however, it has negative relationship between ownership structure and investor reaction. Audit committee independence is negatively related to ownership structure and investor reaction. Lastly, Ownership structure also exhibits a negative relationship with investor reaction.

When correlation test was applied between corporate governance and investor reaction, it highlights that corporate governance has negative relationship with investor reaction.

\section{2) Linear Regression}

OLS regression was applied for testing the hypothesis. i.e. corporate governance has significant impact on investor reaction. The results of OLS regression have been presented in Tables 3 and 4.

When investor reaction was regressed with individual component of corporate governance, it has been seen that there is no impact of corporate governance on investor

Table 1. Individual correlation analysis.

\begin{tabular}{|c|c|c|c|c|c|}
\hline & Board size & Director indep & Audit independ & Ownership & Investor reaction \\
\hline Board size & 1 & & & & \\
\hline Director indep & -0.081483 & 1 & & & \\
\hline Audit independ & 0.078489 & 0.764296 & 1 & & \\
\hline Ownerships & -0.125209 & -0.229453 & -0.145254 & 1 & \\
\hline Investor reaction & -0.005092 & -0.035993 & -0.020992 & -0.049167 & 1 \\
\hline
\end{tabular}

Table 2. Composite correlation analysis.

\begin{tabular}{ccc}
\hline & Cor gov & Investor reaction \\
\hline Cor gov & 1 & \\
Investor reaction & -0.040015 & 1 \\
\hline
\end{tabular}

Table 3. Multivariate linear regression.

\begin{tabular}{|c|c|c|c|c|}
\hline \multicolumn{5}{|c|}{ Dependent variable: investor reaction } \\
\hline \multicolumn{5}{|c|}{ Method: least squares } \\
\hline \multicolumn{5}{|c|}{ Sample (adjusted): 2750} \\
\hline \multicolumn{5}{|c|}{ Included observations: 703} \\
\hline \multicolumn{5}{|c|}{ Excluded observations: 46 after adjusting endpoints } \\
\hline Variable & Coefficient & Std. Error & t-Statistic & Prob. \\
\hline Boardsize & -0.042188 & 0.077682 & -0.543088 & 0.5872 \\
\hline Directorindep & -0.287720 & 0.240102 & -1.198327 & 0.2312 \\
\hline Auditindepend & 0.036783 & 0.080255 & 0.458330 & 0.6469 \\
\hline Ownerships & -0.223137 & 0.135642 & -1.645038 & 0.1004 \\
\hline $\mathrm{C}$ & 0.244078 & 0.208588 & 1.170145 & 0.2423 \\
\hline R-squared & 0.005365 & \multicolumn{2}{|c|}{ Mean dependent var } & -0.009576 \\
\hline Adjusted R-squared & -0.000335 & \multicolumn{2}{|c|}{ S.D. dependent var } & 0.897410 \\
\hline S.E. of regression & 0.897560 & \multicolumn{2}{|c|}{ Akaike info criterion } & 2.628814 \\
\hline Sum squared resid & 562.3186 & \multicolumn{2}{|c|}{ Schwarz criterion } & 2.661213 \\
\hline Log likelihood & -919.0280 & \multicolumn{2}{|c|}{ F-statistic } & 0.941159 \\
\hline Durbin-Watson stat & 2.053108 & \multicolumn{2}{|c|}{ Prob (F-statistic) } & 0.439475 \\
\hline
\end{tabular}


Table 4. Univariate regression analysis.

\begin{tabular}{|c|c|c|c|c|}
\hline \multicolumn{5}{|c|}{ Dependent variable: investor reaction } \\
\hline \multicolumn{5}{|c|}{ Method: least squares } \\
\hline \multicolumn{5}{|c|}{ Sample (adjusted): 2750} \\
\hline \multicolumn{5}{|c|}{ Included observations: 744} \\
\hline \multicolumn{5}{|c|}{ Excluded observations: 5 after adjusting endpoints } \\
\hline Variable & Coefficient & Std. Error & t-statistic & Prob. \\
\hline CORGOV & -0.137214 & 0.125784 & -1.090871 & 0.2757 \\
\hline $\mathrm{C}$ & 0.143569 & 0.139648 & 1.028074 & 0.3042 \\
\hline R-squared & 0.001601 & \multicolumn{2}{|c|}{ Mean dependent var } & -0.004567 \\
\hline Adjusted R-squared & 0.000256 & \multicolumn{2}{|c|}{ S.D. dependent var } & 0.888672 \\
\hline S.E. of regression & 0.888559 & \multicolumn{2}{|c|}{ Akaike info criterion } & 2.604253 \\
\hline Sum squared resid & 585.8363 & \multicolumn{2}{|c|}{ Schwarz criterion } & 2.616651 \\
\hline Log likelihood & -966.7820 & \multicolumn{2}{|c|}{ F-statistic } & 1.190000 \\
\hline Durbin-Watson stat & 2.090652 & \multicolumn{2}{|c|}{ Prob (F-statistic) } & 0.275684 \\
\hline
\end{tabular}

reaction. The value of $\mathrm{R}$-square is $0.53 \%$ which means that this model explains only few factors of corporate governance that affect investor reaction (IR) while 99\% are other factors that influence investor reaction (IR). Fstatistics is insignificant at 0.94 .

When investor reaction was regressed with corporate governance, it has been seen that corporate governance is insignificantly negatively related to investor reaction. The value of R-square is $0.16 \%$ which means that this model explains only $0.16 \%$ of factors of corporate governance that affect investor reaction (IR) while $99 \%$ are other factors that influence investor reaction (IR). F-statistics is insignificant at 1.19.

\section{Conclusions}

Corporate governance is insignificantly negatively related to investor reaction. On the basis of these findings, our hypothesis has been rejected.

Previous studies confirmed the corporate governance practices provide investor protection, due to which investor invest more in those firms which incorporated corporate governance mechanism in their strategic policy.

This study does not support the above justification. One interpretation might be that this study was conducted in inefficient market, due to which investor don't have much knowledge about financial markets. They don't respond to market rationally. Due to this behavior investor creating sentiment in markets and exploit stock return, Noise trader exploit corporate governance practices as well. In such market corporate governance me- chanisms is unable to provide protection to their investors.

\section{Managerial Implications}

Corporate governance has no impact on investor reaction. Therefore, mangers should focus other factors while making their strategic policies to attract their investors, not solely focus on corporate governance

\section{Limitation and Future Research}

In future studies, further variables would be incorporated to investigate the impact of corporate governance on investor reaction. This relationship would be generalized among different economies in order to validate the outcomes.

\section{REFERENCES}

[1] A. H. B. Zulkafli, M. F. bt. Samad, A. Ismail and M. I. Ismail, "Corporate Governance in Malaysia," Working Paper, 2003, pp. 1-19.

http://www.gomalaysiatour.com/administrator/admin/pdf/ 4dcf82cb5b8dc.pdf

[2] J. O. Okpara, "Perspectives on Corporate Governance Challenges in a Sub-Saharan African Economy,” Journal of Business \& Policy Research, Vol. 5, No. 1, 2010, pp. 110-122.

[3] W. G. Schwert, "Using Financial Data to Measure Effects of Regulation,” Journal of Law and Economics, Vol. 24, No. 1, 1981, pp. 121-158. http://dx.doi.org/10.1086/466977

[4] J. J. Binder, "Measuring the Effects of Regulation with 
Stock Price Data,” The RAND Journal of Economics, Vol. 16, 1985, pp. 167-183. http://dx.doi.org/10.2307/2555408

[5] D. F. Larcker, G. Ormazabal and D. J. Taylor, "The Market Reaction to Corporate Governance Regulation,” Journal of Financial Economics, 2011, pp. 1-51.

[6] S. R. Foerster and B. C. Huen, "Does Corporate Governance Matter to Canadian Investors?” Canadian Investment Review (Fall), 2004, pp. 19-25.

[7] N. U. González and F. J. C. Muñoz, "Do Investors React to Corporate Governance News? An Empirical Analysis for the Spanish Market,” Working Paper, 2004, pp. 1-26. https://editorialexpress.com/cgi-bin/conference/download. cgi?db_name=forofinanzas2008\&paper_id=96

[8] G. A. Chavez and A. C. Silva, "Improved Corporate Governance: Market Reaction and Liquidity Implication," Instituto de Empresa Business School Working Paper, 2006, pp. 1-24.

http://latienda.ie.edu/working_papers_economia/WP06-0 8.pdf

[9] A. Nittayagasetwat and W. Nittayagasetwat, "An Analysis of the Stock Price Reaction to Corporate Governance Rating Announcements: The Case of Thai Listed Companies,” NIDA Business Journal, Vol. 1, 2006, pp. 99-111.

[10] C. L. Li, X. H. Li and G. J. Wu, "Corporate Governance, Investor Attention and Post-Earnings Announcement Drift,” 2010. http://papers.ssrn.com/sol3/papers.cfm?abstract_id=5165 $\underline{63}$

[11] R. B. Huang and J. G. Tompkins, "Corporate Governance and Investor Reactions to Seasoned Equity Offerings,” Managerial Finance, Vol. 36, No. 7, 2009, pp. 603-628. http://dx.doi.org/10.1108/03074351011050334

[12] L. F. Klapper and I. Love, "Corporate Governance, Investor Protection, and Performance in Emerging Markets," Journal of Corporate Finance, Vol. 10, No. 5, 2004, pp. 706-728.

http://dx.doi.org/10.1016/S0929-1199(03)00046-4
[13] S. Lee, S. H. Han and M. Kim, "Does Corporate Governance Prevent Information Asymmetry? Evidence from Insincere Announcements of Korean Listed Firms,” Working Paper, 2010, pp. 1-23.

http://papers.ssrn.com/sol3/papers.cfm?abstract_id=1950 103

[14] Y.-W. Chang, R.-D. Chang and J.-T. Wei, “The Effects of Corporate Governance Mechanisms on Investment Decisions," Taiwan Academy of Management Journal, Vol. 8, No. 2, 2008, pp. 1-16.

[15] K. H. Chung and C. H.-H. Shen, “Corporate Governance and Market Reactions to Capital and R\&D Investment Announcements,” 2009.

http://69.175.2.130/ finman/Reno/Papers/CorpGovCapex RnDInvst_Chung_Shen.pdf

[16] R. Aggarwal, I. Erel, M. Ferreira and P. Matos, "Does Governance Travel around the World? Evidence from Institutional Investors,” Journal of Financial Economics, Vol. 100, No. 1, 2011, pp. 154-181. http://dx.doi.org/10.1016/j.jfineco.2010.10.018

[17] J. A. McCahery, Z. Sautner and L. T. Starks, "Behind the Scenes: The Corporate Governance Preferences of Institutional Investors,” Working Paper, University of Amsterdam, 2009, pp. 1-56.

[18] B. J. Bushee, M. E. Carter and J. Gerakos, "Institutional Investor Preferences for Corporate Governance Mechanisms,” Wharton School of Business Working Paper, 2008, pp. 1-49.

[19] J. C. Hartzell, L. Sun and S. Titman, "The Effect of Corporate Governance on Investment: Evidence from Real Estate Investment Trusts (REITs),” 2004.

[20] P. Anglin, R. Edelstein, Y. Gao and D. Tsang, "How Does Corporate Goverance Affect the Quality of Investor Formation. The Curious Case of REITs," Journal of Real Estate Research, Vol. 33, No. 1, 2011, pp. 1-24. 